\title{
Tools to Develop Genetic Model Plants in the Orchidaceae Family
}

\section{Allen Yi-Lun Tsai and Shinichiro Sawa*}

Graduate School of Science \& Technology, Kumamoto University, Kurokami 2-39-1, Kumamoto, Japan

\section{Introduction}

The Orchidaceae family is estimated to contain about 28,000 species and over 100,000 hybrids, making it one of the largest taxonomic groups among flowering plants [1]. The variations in flower colours, floral organ morphology and scents make orchids highly sought-after in ornamental horticulture. In addition, orchids are found in nearly all regions of the world with diverse adaptations, making them an invaluable resource to study plant evolution and speciation.

Despite orchids' great economic values and potential in basic research, currently there are no model plants from the Orchidaceae family. Unlike the model plant Arabidopsis (Arabidopsis thaliana), the orchid genomes are often large, heterogeneous and complex, making genetic analyses difficult [2]. Currently transformation techniques have been developed for several orchid species [3-5], and Virus-Induced Gene Silencing (VIGS) has been used to examine loss-of-function phenotypes [6]. The wind orchid (Neofinetia falcate) is also being advocated as a model plant for its short stature, small genome and large mutant collection [7]. Nevertheless, many barriers still prevent orchids from becoming accessible for genetic analyses. Here we summarize two findings that may help increase the utility of orchids as a genetic model organism.

Firstly, orchid transposons may be a useful tool in mutation mapping. Currently there are no efficient mutagenesis methods for orchids, and the existing mutants are largely isolated and maintained by hobbyists [7]. Transposon may be able to quickly and methodically isolate orchid mutants. Undesirable phenotypic defects can often appear in cell culture clones during commercial breeding, likely due to random transposon excision and re-insertion events. A Phalaenopsis mutant with the floral column partially transformed into petals has previously been identified and characterized [8]. This floral organ conversion resembles the Arabidopsis agamous (ag) mutant, suggesting this mutant is likely affected in a C class floral organ identity gene $[9,10]$. Homologues of floral identity genes have been identified in Phalaenopsis, suggesting orchids may utilize floral development mechanism similar to Arabidopsis $[11,12]$. Furthermore, wild type-like revertants were isolated from the progenies of this Phalaenopsis mutant, indicating the mutation is likely caused by a transposon insertion event, and the phenotype reversed when the transposon is excised [8]. Currently the sequence and identity of this transposon remains unknown, but if this transposon can be identified it may help to develop Phalaenopsis as a genetic model plant. Snapdragon (Antirrhinum majus) is a successful model plant partially due to its genome contains transposons with known sequences. This allows the establishment of transposon tagging lines to easily identify genes affected by transposon insertion [13]. In addition, the function of the gene in question can easily be tested by isolating revertants resulted from the excision of the transposon.

A second challenge in establishing orchid as a model plant is its long generation time. Ornamental orchids typically takes two to three years to propagate one generation, making standard genetic analyses unfeasibly long in orchids. In vitro flowering system has been developed for Dendrobium to accelerate flowering, although its culturing conditions are heavily species-dependent [14]. Recently an Artificial Cultivation System (ACS) was developed to propagate two obligate mycoheterotrophic species, Gastrodia pubilabiata and G. confuse [15]. The ACS set-up consists a cedar $\log$ as growth medium, along with humus and cedar cones to promote fungal growth contained within a plastic box [15]. Interestingly, G. pubilabiata was not only viable in the ACS, but was able to set seeds up to three times a year, compare to in the natural habitat where it may take at least one year to set seed [15]. These results suggest that orchid generation time can potentially be shortened under artificial conditions, such that the timeframes of genetic analyses become feasible.

In summary, advancements in the Orchidaceae family research highlight the orchids' potential to be used as a genetic tool for basic research. One direction is to utilize orchid transposon as a mutation mapping tool. Phenotypic instability is a significant problem in the orchid breeding industry. However if these mutants are indeed caused by transposon insertions, then these mutant populations can be a useful resource to identify novel genes in development. Another advancement is to shorten the orchid generation time. Using the ACS, Gastrodia species can be propagated faster compared to under natural conditions, and currently the Gastrodia inbred line can be maintained up to the F3 generation. In conjunction with the current established molecular genetic techniques and genome annotation efforts, it is conceivable in the near future that genetic analyses in the Orchidaceae family become common practices

\section{References}

1. Hsiao YY, Pan ZJ, Hsu CC, Yang YP, Hsu YC, et al. (2011) Research on orchid biology and biotechnology. Plant Cell Physiol 52: 1467-1486.

2. Lin S, Lee HC, Chen WH, Chen CC, Kao YY, et al. (2001) Nuclear DNA contents of Phalaenopsis sp. and Doritis pulcherrima. J Am Soc Hortic Sci 126: $195-199$

3. Liau CH, You SJ, Prasad V, Hsiao HH, Lu JC, et al. (2003) Agrobacterium tumefaciens-mediated transformation of an Oncidium orchid. Plant Cell Rep 21: 993-998.

4. Hsing HX, Lin YJ, Tong CG, Li MJ, Chen YJ, et al. (2016) Efficient and heritable transformation of Phalaenopsis orchids. Bot Stud 57: 30

5. da Silva JA, Dobránszki J, Cardoso JC, Chandler SF, Zeng S. (2016) Methods for genetic transformation in Dendrobium. Plant Cell Rep 35: 483-504.

6. Lu HC, Chen HH, Tsai WC, Chen WH, Su HJ, et al. (2007) Strategies for functional validation of genes involved in reproductive stages of orchids. Plant Physiol 143: 558-569.

7. Duttke S, Zoulias N, Kim M. (2012) Mutant flower morphologies in the wind orchid, a novel orchid model species. Plant Physiol 158: 1542-1547.

8. Ejima C, Kobayashi Y, Honda H, Shimizu N, Kiyohara S, et al. (2011) A Phalaenopsis variety with floral organs showing $\mathrm{C}$ class homeotic transformation and its revertant may enable Phalaenopsis as a potential molecular genetic material. Genes Genet Syst 86: 93-95.

9. Bowman JL, Smyth DR, Meyerowitz EM. (1989) Genes directing flower development in Arabidopsis. Plant Cell 1: 37-52.

10. Bowman JL, Smyth DR, Meyerowitz EM. (1991) Genetic interactions among floral homeotic genes. Development 112: 1-20.

*Corresponding author: Sawa S, Professor of Science \& Technology , Graduate School of Science \& Technology, Kumamoto University Kurokami 2-39-1, Kumamoto , Japan, Tel: 096-342-3439; E-mail: sawa@kumamoto-u.ac.jp

Received July 10, 2018; Accepted July 23, 2018; Published July 30, 2018

Citation: Tsai AY, Sawa S (2018) Tools to Develop Genetic Model Plants in the Orchidaceae Family. Mol Biol 7: 217. doi: 10.4172/2168-9547.1000217

Copyright: ( 2018 Tsai AY, et al. This is an open-access article distributed under the terms of the Creative Commons Attribution License, which permits unrestricted use, distribution, and reproduction in any medium, provided the original author and source are credited. 
11. Wang HM, Tong CG, Jang S. (2017) Current progress in orchid flowering/ flower development research. Plant Signal Behav 12(5): e1322245.

12. Su CL, Chen WC, Lee AY, Chen CY, Chang YC, et al. (2013) A modified $A B C D E$ model of flowering in orchids based on gene expression profiling studies of the moth orchid Phalaenopsis aphrodite. PLoS One 8: e80462.

13. Carpenter R, Coen ES. (1990) Floral homeotic mutations produced by transposon-mutagenesis in Antirrhinum majus. Genes Dev 4: 1483-1493.
14. Teixeira da Silva JA, Zeng SJ, Dobránszki J, Cardoso JC, Kerbauy GB (2014) In vitro flowering of Dendrobium. Plant Cell Tiss Organ Cult 119: 447-456.

15. Shimaoka C, Fukunaga H, Inagaki S, Sawa S. (2017) Artificial Cultivation System for Gastrodia spp. and Identification of Associated Mycorrhizal Fungi. Int J Biol 9: 27-34. 